Revista Iberoamericana, Vol. LXVIII, Núm. 199, Abril-Junio 2002, 269-281

\title{
DESEOS DE LITERATURA: AUTORES SUCEDÁNEOS EN DOS PELÍCULAS DE ELISEO SUBIELA - ÚLTIMAS IMÁGENES DEL NAUFRAGIO Y EL LADO OSCURO DEL CORAZÓN
}

POR

\author{
GeOFFrey Kantaris \\ St Catharine's College \\ University of Cambridge
}

No vengo acá para hablar de literatura, muñeco. Éste es un cabaret; no es un club literario.

- Ana, El lado oscuro del corazón

El presente trabajo estudia la “función literaria” en el cine desarrollada en dos textos cinematográficos de Eliseo Subiela, uno de los directores más conocidos de la Argentina. Mi intención es ir más allá de los paradigmas comunes de adaptación literaria e influencia literaria, así como de los modelos fijos de la especificidad cinematográfica, con la idea de sugerir que la literatura representa una condición limítrofe para el cine, un sistema delimitador y un dispositivo enmarcador que a su vez está consumido dentro de la logofagia frenética del cine. Se ha escrito mucho sobre el régimen scopofílico del cine, a través del cual el consumo de imágenes viene a sustituir la falta constitutiva en la relación del sujeto con la pantalla, a menudo proyectada en la figura de una mujer; ${ }^{1}$ menos se ha escrito recientemente en torno a su deseo de conseguir un dominio lingüístico y de constituir un significante totalizador. Los teóricos del cine clásico prestaron atención al lenguaje del cine (Metz), al cine como texto y como écriture (el propio Subiela cita el concepto de Astruc de la "caméra-stylo" en una entrevista reciente). ${ }^{2}$ Sin embargo, en este trabajo estoy menos interesado en la textualidad del cine que en su deseo por el texto (literario); mi planteamiento está basado en la idea de que la literatura misma se convierte tanto en objeto como en significante del deseo en las obras de Subiela. A través de la proliferación de citas literarias, de autores sucedáneos y de juegos genéricos, el espacio de representación literaria en estas películas establece un complejo sistema de interacciones de marco y referencia, límite y significación.

Ninguna de las películas de Subiela puede ser considerada como adaptación, a menos que sea posible describir una película como la adaptación de un poema. Desde sus primeros trabajos, Subiela ha mostrado un compromiso con la literatura en sus obras

\footnotetext{
${ }^{1}$ El término scopofilia, muy difundido en la teoría del cine, se refiere al deseo y placer de mirar; se asocia con el voyeurismo como rasgo esencial en la relación entre el espectador y la pantalla. ${ }^{2}$ Véase "Entrevista a Eliseo Subiela.” En torno a la relación entre cine y literatura, el estudio más interesante, meticuloso y visionario continúa siendo la obra de Keith Cohen, Film and Fiction: The Dynamics of Exchange.
} 
cinematográficas. Su primer largometraje, La conquista del paraíso (1980), albergaba la huella de Los pasos perdidos, de Alejo Carpentier, y trataba sobre un personaje que ansiaba ser escritor-cineasta. ${ }^{3}$ El nombre de un protagonista de la película Hombre mirando al sudeste (1986), el doctor Julio Denis (Lorenzo Quinteros), psiquiatra y saxofonista, era, y no casualmente, el pseudónimo con el que Julio Cortázar publicó sus primeras obras literarias; además, el escenario del asilo, con su exploración metafísica de los límites entre locura y civilización, entre “el lado de acá” y “el lado de allá”, traía reminiscencias de la segunda parte de Rayuela. ${ }^{4}$ Asimismo, su siguiente largometraje, Últimas imágenes del naufragio (1989), trataba sobre un vendedor de seguros y escritor “fracasado”, Roberto (también interpretado por Lorenzo Quinteros), cuya imaginación se desata a partir de su encuentro con una típica amante modernista, Estela (Noemí Frenkel). ${ }^{5}$ Su caracterización rememora a la Nadja de André Breton o a La Maga, de Cortázar (como Nadja y La Maga, Estela es descrita como "la portadora de una llave”, 0:13). La novela que Roberto comienza a escribir sobre ella se titula (irónicamente) “Informe sobre Estela" (0:14), referencia que se añade a una cita visual que aparece más adelante en la película a la obra de Ernesto Sábato, Informe sobre ciegos. ${ }^{6}$ Una escena de discoteca nos recuerda el relato de Cortázar "Las puertas del paraíso”, mientras abundan las referencias arltianas (por ejemplo, la búsqueda de la salvación en "un billete de lotería, un gran robo, un invento genial”, 0:04). ${ }^{7}$ Pero Roberto asimismo lee a Oliverio Girondo durante sus descansos para el almuerzo, y es precisamente la poesía de vanguardia de Girondo de los años treinta, junto con la de Mario Benedetti y Juan Gelman, la que inunda la textura de la película que se estrenó en 1992, El lado oscuro del corazón. Esta película proyecta multitud de motivos literarios en la caracterización de Oliverio Fernández (Darío Grandinetti), ${ }^{8}$ un inquietante poeta que pasa sus días (y noches) en busca de una mujer que "sepa volar” (del Poema I del volumen Espantapájaros, 1932, de Girondo), a la que finalmente encuentra en la forma de una prostituta muy versada de Montevideo, Ana (Sandra Ballesteros), quien, desafortunadamente para él, tiene otras prioridades. La película realiza una combinación de poesía, erotismo, música emotiva, alegoría visual, e iconoclastia que lleva a una

\footnotetext{
${ }^{3}$ Véanse los comentarios sobre la película que hace Ricardo Manetti (120), quien ofrece un panorama muy útil para estudiar la producción cinematográfica de Subiela.

${ }^{4}$ Encontramos otras referencias culturales claras en Hombre mirando al sudeste, aparte de la Biblia, a Magritte, Proust, La invención de Morel de Bioy Casares, a la obra de ciencia-ficción del escritor Philip K. Dick, y a la película Blade Runner (1982), basada en una de las novelas de Dick. Véase Grant, “Giving Up Ghosts” para un estudio de la relación con Bioy Casares, y Kantaris, "Holograms and Simulacra”, para un estudio de los paradigmas de la ciencia-ficción.

${ }^{5}$ En el presente trabajo, uso los términos modernismo y modernista en el sentido anglosajón para referirme a una versión cinematográfica de las estéticas desarrolladas por las vanguardias literarias y artísticas de los años veinte y treinta.

${ }^{6}$ Informe sobre ciegos es un fragmento de la novela de Sábato Sobre héroes y tumbas, pero también fue publicado por separado.

${ }^{7}$ Manetti señala que el protagonista, Roberto, lleva el nombre de Arlt y sostiene que la caracterización de la familia de Estela está sacada del sub-mundo arltiano (120-21).

${ }^{8}$ Roberto Forns-Broggi (466) destaca que este nombre condensa a las figuras literarias de vanguardia: Oliverio Girondo y Macedonio Fernández.
} 
poderosa mezcla, aunque a veces exagerada. Además, la fórmula tuvo tanto éxito que en una jugada bastante kitsch, Subiela sacó El lado oscuro del corazón II en 2001, con una acogida crítica bastante escéptica. Las películas que hizo en el lapso entre los dos Lados oscuros también incluían diversas referencias literarias, como la quema de libros “subversivos" en Despabilate, amor (1996), las lecturas de Pessoa en Pequeños milagros (1997), o la inspiración de Las aventuras de Dios (2000) en la técnica surrealista de la escritura automática; no obstante, los elementos literarios estaban menos presentes en el tema y estructura de estas películas que en sus primeros trabajos.

¿Cómo se puede explicar esta proliferación de referencias y encuadres literarios? ¿Cuál es su función — o qué carencias suplen— en la estética cinematográfica de Subiela? Para contestar a estas preguntas voy a concentrarme en Últimas imágenes del naufragio y El lado oscuro del corazón, ${ }^{9}$ dos películas que considero paradigmáticas en términos de la exposición de la función literaria en el cine así como en la estética del director. Fredric Jameson ha sugerido que cuando una película inserta imágenes de otros modos estéticos o de otros medios dentro de su encuadre, lo hace para poner en escena su superioridad, "to set off and demonstrate film's ontological primacy” (62). En otro artículo sostengo que, más que demostrar primacía ontológica, lo que sucede es que los diferentes modos estéticos se relativizan de inmediato una vez citados dentro de la película; en otras palabras, se convierten en imágenes citadas de ellas mismas, simulacros, o modelos genéricos (Kantaris, “The Last Snapshots” 232). Sin embargo, en el presente trabajo me gustaría explorar una interrelación más compleja. No discuto el hecho de que el discurso literario en el cine simule, efectivamente, "la literatura" o "lo estético" per se para apropiarse de su aura (puesto que la literatura presenta la imagen de un sistema significativo utópico y coherente dentro del marco de la significación cinematográfica). Más bien quisiera añadir a esta observación la siguiente propuesta: la presencia del discurso literario en el cine pone en marcha un proceso canibalístico que subordina el significante cinematográfico a (la imagen de) otro marco de significado más completo y trascendental, o sea el marco literario. El cual, además, organizaría y apaciguaría los excesos (la heterogeneidad y la diferencia) que constituyen la significación cinematográfica.

Este acercamiento es válido específicamente en el análisis de películas en las que domina una estética modernista (sea parodia o no), que suelen incluir la mayoría de las manifestaciones del cine de autor. ${ }^{10}$ No es casual que las películas de Subiela abunden en autores sucedáneos cuya función parece ser la de servir de contrapunto al proceso de creación de significados de las películas, para actuar de manera simultánea como punto de apoyo en la cadena de significación (empleando sistemas de organización y restricción estética) y como focos de autorreflexión para el posible fracaso de sus propios proyectos estéticos - y por tanto de los de las películas. Y tampoco es casualidad que las principales fuentes literarias de Subiela sean textos de la vanguardia, llenos de narradores

\footnotetext{
${ }^{9}$ He escogido el original, porque la remake, como bien ha explicado Mauricio Alonso, falla porque carece de un rasgo que prevenga a lo fantástico-metafórico de caer en el ridículo: el elemento de la sorpresa.

${ }^{10}$ Véase Pinkney para una exposición interesante de las conexiones entre el auteurism y el modernismo (en el sentido anglosajón).
} 
autorreferenciales que buscan a través de la experimentación textual, una salida de lo meramente textual, trascender la estética a partir de la estética y, de esta forma, liberar modos de autenticidad. En estas películas, la vida en la Argentina neoliberal después de la dictadura se retrata como una ficción o representación asfixiante:

Para mi esposa la vida era una obra de teatro. Para mí, una novela. Nuestras vidas no parecían ser otra cosa que una representación. Una representación que me estaba asfixiando... Decidí bajarme del escenario. (Roberto, voz en off, Últimas imágenes, 1:06)

Y tú, que trabajás con tu imaginación, cuando no la convertís en una puta imaginación para conseguir unos putos dólares, que te permiten estar con una puta mujer, ¿cómo te imaginás que fue mi puta vida? (Ana, la prostituta, habla con Oliverio, El lado oscuro, $1: 12)$

En ambas películas, como en muchos textos vanguardistas-modernistas, la libertad y la autenticidad (en oposición a la rutina agobiante de la existencia urbana o a la transformación del arte en producto comercial) se proyectan en la figura de la prostitutaamada literaria; sin embargo, en las dos películas se complica la búsqueda de la verdad de los protagonistas masculinos a través de los cuerpos y narrativas de estas mujeres, puesto que en cada caso las prostitutas están caracterizadas en términos de performance (representación), teatralidad y duplicidad. Además, como Joanna Page sostiene en relación a El lado oscuro, "Comparisons are frequently implied between poetry and prostitution: both comprise performance of a highly stylized nature; both are essentially founded on an economic transaction, being explicitly dependent on rich Japanese clients for survival” (390). La ansiedad que se genera por la refundición de la autenticidad y la performance - la incertidumbre que recae en los efectos verídicos generados a través de la ficción - se lleva al escenario de una forma muy deliberada, siendo, hasta cierto punto, el argumento de las dos películas.

Estela, en Últimas imágenes, comienza poniendo en escena una fantasía masculina de rescate, en la que finge intentar suicidarse en la estación del subte para atraer a clientes. Esta representación genera un texto, sin ser consciente de ello, ya que, Roberto, el escritor frustrado, ve en ella la realización de su búsqueda de "una sola palabra [que] podría ser el comienzo de esa gran novela que me rescataría de una muerte tan segura, tan correcta" (0:05). Paga a Estela para que le cuente su historia, más que por sexo (de esta manera se mezclan prostitución y literatura), y Roberto pronto descubre que la seguridad de los límites entre ficción y realidad comienza a erosionarse.

Uno de los hermanos de Estela, Claudio (Hugo Soto), que es un desequilibrado mental, viene a visitarlo y le ofrece dinero para que escriba “episodios” para los miembros de su familia disfuncional. Otro hermano, José (Pablo Brichta), que es un ladrón, cuando abandona sus sospechas de que Roberto pueda ser un policía, lo convence para que se asocie con él para crear argumentos interesantes que puedan llevarse a cabo en sus atracos a mano armada: "Nunca te van a pagar tanto por tu imaginación. Te estoy ofreciendo la liberación, macho” (1:21). La película aquí maneja el tema arltiano del ladrón como transgresor de las convenciones sociales que subyacen un principio de realidad controlado 
y violento: "si no hubiera sido chorro, me hubiera gustado ser actor" (0:57), dice José. Los argumentos de Roberto combinan ambos papeles, y sugieren, en un momento utópico (modernista), que la ficción puede transgredir la ficción de lo social, puede ofrecer liberación, tal y como la falsificación transgrede la ficción del dinero en las novelas de Arlt. Sin embargo, el inevitable plano hollywoodense del dinero flotando sobre la cama (1:33) sugiere el desmoronamiento de este tema modernista de la ficción a través de la ficción, precisamente porque se cita de manera autorreferencial como cliché.

Roberto, sin embargo, se ve metido en un problema mayor conforme el desmoronamiento de los límites entre ficción y realidad lo arrastra dentro de las tramas que cree estar escribiendo para otros. En un momento del final de la película, Estela pregunta a Roberto cómo aparece retratada ella en su novela, algo que, como ya hemos comprobado, se deriva de escritores como Arlt y Sábato:

Estela: ¿Cómo soy en la novela?

Roberto: Parecida.

Estela: ¿Cómo se llama el personaje?

Roberto: Estela.

Estela: ¿Y hace las mismas cosas que hago yo?

Roberto: Algunas... Sólo que cuando ella ... finge que va a tirarse debajo del tren para conseguir algún cliente, en realidad está mintiendo. Iba a tirarse de verdad.

Estela: Pobre Estelita. (1:34)

Claramente, la propia estética performativa de Estela es bastante más sofisticada que el cliché de la estética de la mímesis y la autenticidad que despliega Roberto en su novela. Roberto intenta fundar la perturbadora mezcla de ficciones y simulaciones en una retórica de la verdad: detrás de su performance, Estela en realidad necesita que la salven. Para subrayar este punto, Roberto sugiere que vuelvan a representar la escena del intento de suicidio en varias estaciones del subte, para que pueda observar a los que intentan salvarla. Estela, perturbada por la sugerencia, accede a realizar la mímica del mimo, y nosotros, junto con Roberto, observamos de nuevo la puesta en escena desde varios ángulos de cámara (plano general desde el andén del otro lado, plano medio a nivel bajo que encuadra los pies de Estela, seguido por un retrato de perfil, 1:35), que recuerdan también a nivel de montaje la secuencia “original” de intento de suicidio que aparece al principio de la película. La última representación, en la que Estela se salva a sí misma porque no hay nadie más que lo pueda hacer por ella (incluso Roberto la abandona en el andén), se corta en el plano de un ciego, con bastón y gafas oscuras, que va caminando por el andén del metro, algo que retoma, visualmente, la referencia al Informe sobre ciegos de Sábato que ya hemos mencionado con anterioridad. Mientras esta referencia literaria podría simplemente servir como establecimiento de una línea temática sobre la ceguera y la visión (que comentaremos más adelante), creo que también debilita, en su momento más conmovedor, la narración de la auténtica salvación en la que Roberto intenta, a través de una repetición compulsiva de auto-terapia, situar a Estela y a su extraña familia. Sin embargo, exploremos a continuación las implicaciones más amplias (de carácter político) de esta narrativa de salvación, ya que representa en cierta manera el quid de los efectos de encuadre en ambas películas. 
En diversos momentos de Últimas imágenes, así como en El lado oscuro, se insinúa que el último marco de referencia en la aterrorizada mezcla de ficción y disimulo se encuentra en la terrible dictadura militar de los años 1976-1982. La primera mención de la misma aparece en una discusión entre Roberto y Claudio que se sitúa, significativamente, en una librería, en la que Claudio cuenta cómo fue arrestado por la policía cuando era un estudiante y la decisión que tomó de aceptarlo para sobrevivir (0:34). Su manía de eliminar palabras de su vocabulario, algo que hace que su discurso se vea interrumpido por silencios cada vez más largos conforme se desarrolla la película (y que va en contra de la continuidad cinematográfica), parecería encontrar su explicación verdadera en la referencia histórica y más específicamente, en la represión militar y la censura. De igual forma, la renuncia de la figura de Cristo, que Estela se encuentra dos veces en una iglesia, debido a su incapacidad de perdonar la hipocresía de "quienes desgarraron la carne de sus semejantes” (1:24), apunta claramente hacia la tortura como una de las lagunas en las narrativas nacionales de salvación y naufragio. Y son precisamente los efectos de tan poderosa verdad a los que se aluden en las consecuencias de la auto-salvación de Estela, que parecerían convertir su performance ficticia y repetida en una especie de terapia, una historia verdadera de salvación. Mientras Estela sale del andén para buscar a Roberto, quien la había dejado a su suerte, en el pasillo que conecta la estación por arriba, la cámara realiza un travelling a lo largo de un mural que hay en la pared del pasillo, que representa cabezas deformadas presididas por un triunvirato de figuras con aspecto de militares: uno lleva gafas oscuras, otro levanta el brazo en posición de saludo, y el tercero lleva una boina de soldado; después de este travelling, la cámara se para en Estela y Roberto. “¿Quién te salvó?” pregunta Roberto. “Nadie,” responde ella, “me salvé sola. No sé qué hubiera hecho tu Estela. Yo no quiero morir” (1:37). Parecería que la estrategia de Roberto funciona: la ficción y la realidad están separadas y a salvo de nuevo; los simulacros han regresado a sus referentes históricos y una narrativa de auto-salvación ha venido a sustituir los males del pasado.

Esta escena se corta de inmediato y nos traslada a una sala de cine en la que Estela, Roberto y José están sentados entre una gran masa de espectadores que ven la película Tiempo de revancha, de Adolfo Aristarain (1983), una de las primeras películas de la "post-dictadura” que, curiosamente, fue proyectada por primera vez un año antes de que se volviera a la democracia. El escenario del cine, siempre autorreflexivo en una película, con el fondo de una película sobre el silencio, la disimulación y la auto-censura, hace que continúen las tensiones que existen entre ficción y efectos verídicos, y entre historia ficticia e historia real. De repente, José se pone unas gafas oscuras y un bigote de mentira, el mismo disfraz que le hemos visto llevar en una de sus “tramas” de robos a mano armada escritas por Roberto, y se marcha del teatro para atracar la taquilla y matar al encargado. A la tarde siguiente (en una interpretación magistral de la actriz Noemí Frenkel), una furiosa Estela aparece en la habitación de hotel de Roberto, abre la puerta de un golpe y le grita:

Se acabó, Roberto. Fuiste demasiado lejos. [...] Me contó José que los últimos asaltos los planificaron juntos. [...] ¿Tú no te das cuenta que José es un enfermo? ¿Qué clase de hijodeputa sos? ¿Qué somos? Tus personajes, ¿no? ¿Eh? [Coge páginas de un guión 
escrito a máquina del escritorio de Roberto, las arruga y se las lanza a él] ¿Y ahora qué vas a hacer? [Gritando] ¿Qué vas a hacer con José que mató a un tipo? ¿Qué vas a hacer? [Empuja y golpea a Roberto] ¡Decime! ¿Cómo sigue el próximo capítulo? ¿O todavía no llegaste a esta parte de la novela? (1:40)

A continuación se sube encima del escritorio, abre la ventana y se burla de Roberto, "Pensás que puedo tirarme, ¿no? ¿Eh? Sería un final que lo tendrías que pensar vos.” Situando las piernas sobre la máquina de escribir, que tiene una página a medio escribir, vuelve a burlarse, “A ver si un personaje te puede hacer esto”, y orina encima de la máquina de escribir. Esta secuencia, con su inversión modernista y unamuniana de jerarquías literarias de autor y personajes, sirve, desde mi punto de vista, para reencuadrar las narrativas de salvación que, durante un tiempo, parecían haber puesto al mismo nivel la novela de Roberto y la propia película, y haber estabilizado la relación entre ficción y referente histórico. Los personajes se niegan a permanecer contenidos en las narrativas prescriptas y predecibles de salvación y autenticidad que escribe Roberto. Se salen del marco del entramado que éste ha diseñado cuidadosamente para ellos, al igual que la propia película continuamente se desencuadra y reencuadra a sí misma en la sala de espejos de las citas literarias y cinematográficas.

No es una sorpresa, pues, que de todos los planos de Últimas imágenes del naufragio que Subiela podría haber escogido para citar en El lado oscuro del corazón, de 1992, escogiera el de Roberto y Estela viajando en un vagón del subte entre repetidas interpretaciones de la puesta en escena de su suicidio. La cita se inserta, a la manera de Krzysztof Kieslowski, ${ }^{11}$ en una secuencia en la que Oliverio viaja en el subte con el personaje alegórico La Muerte (Nacha Guevara), que presenta un momento de vacilación y auto-duda, extraña, aunque posmoderna, en torno a la verdad de su misión y finalidad: "Sería horrible darse cuenta que ... que nunca hubo nadie, ¿no?... Que trabajo para nadie, o para nada [...] Así que sería espantoso descubrir que cumplo órdenes ... que nadie ha dado” (1:05). La inserción que sigue, encuadrada como punto de vista desde la perspectiva de Oliverio, es un plano medio de Roberto y Estela de pie, mudos y tristes, al otro lado del vagón; ésta es la única aparición de estos personajes en El lado oscuro. Más que sugerir líneas de argumentos contemporáneos o que se interconectan (Últimas imágenes está situada en 1982 ó 1983, mientras que El lado oscuro está situada siete u ocho años después de la reinstauración de la democracia en Uruguay), ${ }^{12}$ esta cita parece sugerir, incluso de manera más perturbadora, que Roberto y Estela todavía siguen rondando las estaciones del subte, atrapados en su repetición compulsiva de la interpretación teatral y la disimulación ficticia — es más, atrapados dentro de la narración fílmica— que permanece sin resolverse, incluso dentro de todo el marco narrativo de la película anterior.

\footnotetext{
${ }^{11}$ Subiela es admirador de Kieslowski e incluye una toma de un póster de Bleu en la película de 1995, No te mueras sin decirme adónde vas (nótese que Bleu fue estrenada un año después de El lado oscuro).

${ }^{12}$ Ana tiene treinta años y le dice a Oliverio que tenía veintidós o veintitrés cuando la dictadura acabó (1:12), aunque no hay razones que nos lleven a pensar que dice la verdad sobre su pasado. Últimas imágenes se puede fechar aproximadamente, por la proyección de la película de Aristarain Tiempo de revancha, en la secuencia mencionada anteriormente.
} 
A nivel de montaje, la cita funciona de un modo aun más complejo: de manera autoconsciente se extiende fuera del marco de referencia de la película y dentro de lo que se llama parergon, siendo éste el único espacio en el que la cita se puede leer. El concepto de parergon tal y como se aplica a la representación artística aparece desarrollado en el texto de Jacques Derrida The Truth in Painting, en el que se define como un espacio que "[is] neither work (ergon) nor outside work, neither inside nor outside, neither above nor below, it disconcerts any opposition [...] and it gives rise to the work" (9). No se trata simplemente de un marco cualquiera, sino de aquél "[that] works the frame, makes it work, lets it work, gives it work to do” (12). Puede imaginarse como el espacio, conceptual, emotivo, de la experiencia, etc., entre el espectador y la obra de arte (Fuery 152-57). Decir que la cita transfílmica ocupa un espacio parergonal no es lo mismo que decir que la película requiere conocimiento contextual para descodificar su sistema de significados todos los textos presuponen cierto tipo de conocimiento. Lo que es diferente en este tipo de citas es que, para aquéllos que las pueden detectar, éstas destacan el funcionamiento del encuadre que normalmente permanece oculto, y por lo tanto, representan un intento consciente de extender el sistema de representación de la película al espacio que hay más allá del encuadre. Al utilizar la convención ya normalizada del plano subjetivo para intentar un puente de montaje a través de una distancia temporal y espacial posiblemente muy grande, ésta se extiende e invade el espacio extracinematográfico entre la proyección de dos películas diferentes. ${ }^{13}$

Estamos acostumbrados a modos de montaje que sirven como puente entre diferentes espacios o tiempos. Pero podemos encontrar más ejemplos a lo largo de El lado oscuro, que rompen con las convenciones que rigen lo que puede cortarse dentro de los límites de continuidad, llevando los efectos de enlace entre planos hasta extremos de autorreflexividad. A los cinco minutos de comenzar la película, se ve un plano general que muestra a Oliverio comiendo en un buen restaurante en Montevideo, seguido de un plano de Ana, la prostituta, comprando verduras y después comiendo sola una pequeña comida en la mesa de madera de su cocina; le sigue un plano medio frontal de Oliverio, con la mirada de quien ha visto algo o a alguien justo a la derecha de la cámara; después, un contraplano de Ana, todavía comiendo, que de repente mira como si estuviera siendo observada; contraplano de Oliverio, bajando los ojos como si le hubieran pillado mirándola. La secuencia juega muy acertadamente con dos convenciones cinematográficas: la mirada típica de dos futuros amantes que atraviesa un espacio vacío o lleno de gente, convención que ahora se encuentra naturalizada como escena prototípica del cine de reconocimiento casi especular, y que inaugura todo un régimen de scopofilia; y el encuadre de esta mirada prototípica a través del juego con las convenciones narrativas de montaje cinematográfico. Sin embargo, el ejemplo más espectacular de El lado oscuro, que conscientemente une esta técnica a las fórmulas literarias, es la secuencia en la que Oliverio, en Buenos Aires, y Ana, en Montevideo, parecen entablar un diálogo (poético) desde ambos lados de la enorme

\footnotetext{
${ }^{13}$ Aquí Subiela está jugando con las convenciones del montaje cinematográfico que dan la ilusión de continuidad temporal y ayudan a poblar el espacio imaginario alrededor del marco de cada escena. Los planos subjetivos y el montaje plano-contra plano (por ejemplo en el diálogo) normalmente crean estas ilusiones.
} 
extensión del Río de la Plata (1:46). Esta ilusión sólo se hace posible en ambos casos gracias a la sutura imaginaria del montaje plano-contra plano, tal y como Page señala (393), que aquí se extiende de manera imposible sobre una enorme distancia geográfica. Y es la propia poesía, es decir, las palabras que los personajes recitan, la que es impulsada a tomar el papel de agente de sutura, forzada a compensar el vacío temporal y espacial que amenaza con trastornar la continuidad del flujo fílmico. A la vez que funciona en un espacio indeciso tanto dentro como fuera de la obra, insinuando a nivel diegético la superación de esa distancia entre los amantes a través de la poesía, y a nivel extra-diegético poniendo de relieve el corte que subyace toda "continuidad” fílmica, esta secuencia expande de un modo dramático la función de la poesía en la película, proyectándola en el espacio parergonal que se activa y funciona sobre el encuadre.

Aparte de la cita de Últimas imágenes, hay otra referencia a la obra del propio Subiela que parece poner de manifiesto de manera explícita la relación entre lo visual y lo verbal: es una referencia a la película de Subiela, Hombre mirando al sudeste, y ocurre cuando Oliverio seduce y hace el amor con una mujer ciega, interpretada por Inés Vernengo. En el momento del clímax, ella exclama una sola palabra, “azul” (0:56). En Hombre mirando al sudeste, Beatriz Dick (llamada así en homenaje al autor de ciencia-ficción Philip K. Dick), también conocida como "la Santa”, expulsa por la boca un líquido azul en un momento de clímax similar; la actriz es, por supuesto, Inés Vernengo (aunque el personaje en la película mencionada no es ciega). Hay un deslizamiento entre lo visual y lo verbal en esta cita, que se encuentra en el núcleo de la mezcla de imágenes de la película en conjunto: una referencia puramente verbal en El lado oscuro cita lo que se había mostrado visualmente en la película anterior, expandiendo así el tema de la ceguera (que se encuentra en el límite de significación del cine) de nuevo en el espacio parergonal entre dos proyecciones (para las cuales, además, el nexo de unión es la actriz y no el personaje en sí). Además, me gustaría plantear que esta expansión al parergon, este encuadre del encuadre, es un rasgo constitutivo de las citas intertextuales en el cine en general, que se recalca de modo autorreflexivo en la estética de Subiela. La ceguera es uno de los motivos que aparecen continuamente a lo largo de sus trabajos, desde la mención a Sábato en Últimas imágenes, como ya hemos visto, pasando por la exploración de lo táctil como elemento para ser traducido al lenguaje visual y auditivo del cine, durante la escena de amor con la mujer ciega en El lado oscuro, hasta la exploración de la conexión entre lenguaje y visión en Pequeños milagros (1997). La protagonista de esta última película decide trabajar de voluntaria como lectora de ciegos; la interconexión entre lo visual y lo verbal se presenta de manera más concreta en las secuencias en las que lee la obra de Pessoa a un viejo ciego a quien inspira una pasión, tan intensa como dolorosa a causa de la imposibilidad de que se cumpla. No es casualidad que, en cada uno de estos casos, la ceguera esté asociada tanto con lo verbal como con lo abiertamente literario, ya que la ceguera en el cine se sitúa en los bordes de su régimen scopofílico y opera precisamente en ese espacio incierto, parergonal, transitorio, en el que el lenguaje (y lo literario) activa el marco de lo visual.

El lado oscuro del corazón es una película deliberadamente provocativa en muchos sentidos. Su retrato de la sexualidad masculina podría parecer tremendamente convencional: sus protagonistas masculinos son playboys de mediana edad y divorciados obsesionados 
con sus penes; su visión de las mujeres está llena de clichés típicos (tanto seductoras prostitutas como mujeres "sensatas" que se han vendido al sistema familiar burgués y que han pactado con la Muerte, o madres que son representadas, literalmente, como vacas); los hombres en la película quieren promiscuidad/libertad, mientras que las mujeres quieren compromiso/seguridad (Ana la prostituta es la única mujer que de alguna manera se escapa de estos clichés); el modelo de (hetero)sexualidad es el de la complementariedad frustrada, el de la búsqueda de satisfacción y culminación sexual que solamente puede terminar en fracaso (y el fracaso es parte de la repetición compulsiva que supone el deseo). El encuadre que la película hace de la estética es igual de estereotipado: el arte y la poesía son emanaciones de autenticidad y “sentimientos verdaderos” frente a la explotación comercial; el poeta es el inquietante bohemio que vive y que sobre todo siente lo que escribe; la poesía debería declamarse, preferiblemente acompañada de música emotiva, y representa un lenguaje “especial” que rescata momentos de verdad de las garras de la muerte/materialidad (incluso cuando depende de capital extranjero para su existencia); sobre todo, la poesía es una buena manera de coquetear, básicamente una extensión de una libido masculina obsesiva y cosificadora. Sin embargo, entre este catálogo de clichés, lo que permite que la película funcione como centro de una experiencia que se extiende más allá del estereotipo es su insistente auto-encuadre, o más bien el proceso continuo de desencuadre y reencuadre que se pone en juego en la exploración de las conexiones entre lo verbal y lo visual, entre lo literario y lo cinematográfico.

La revista crítica de cine El amante cine, que ha desarrollado una corriente editorial consistente y moralista a favor de un cine anti-ilusionista, de carácter histórico y político, y que suele ser hostil en extremo hacia la particular mezcla de fantasía y surrealismo de Subiela, ha acusado repetidas veces a la obra de Subiela de echarse a perder por culpa de ser demasiado literal en su uso de imágenes fantásticas y consecuentemente de caracterizarse por "la ausencia del cine” (por la cual también se refieren posiblemente al exceso de lo literario; véase Villegas y Noriega). Si dejamos a un lado la noción rígida y prescriptiva de lo que debería constituir el cine, desde mi punto de vista, es precisamente el continuo proceso que realiza Subiela de traducción constante entre lo literal-literario y lo visualimaginativo el que pone en funcionamiento el encuadre, el cual además complica cualquier lectura literal de las posiciones del sujeto dentro de estas películas. Coincido con el análisis de Page, quien sostiene firmemente que el uso que la película hace de los estereotipos es una estrategia posmoderna que, además, es consciente del lugar histórico y político que ocupa (frente a las afirmaciones radicales que se hacen a menudo de la relación entre el posmodernismo y la crítica social). Tomemos sólo dos ejemplos: la primera secuencia de la película (antes de los créditos), en la cual Oliverio, tumbado en la cama desnudo, recita parte del primer poema del Espantapájaros de Girondo a la mujer que lo mira escéptica a su lado ("no les perdono [a las mujeres], bajo ningún pretexto, que no sepan volar”), para convertir después en literales las imágenes del poema echándola a volar al vacío a través de una trampilla en su cama; y una secuencia a la mitad de la película en la que Oliverio se arranca literalmente el corazón del pecho como parte de su strip-tease en el club Sefiní, acompañado por las palabras del bolero “Algo contigo” de Chico Novarro. En ambas secuencias es la traducción de lo lingüístico a lo visual y viceversa la que precisamente deja un espacio en blanco en la repetición cinematográfica de papeles 
pre-configurados, en los discursos empaquetados de amor y sexualidad, de la misma forma que deja un espacio en blanco en las presuposiciones estéticas que extraerían alguna distinción esencial entre un poema y un bolero.

Lo que finalmente emerge de los complejos efectos del encuadre entre categorías estéticas en esta película, al igual que en Últimas imágenes, es una exploración del deseo cinematográfico hacia la literatura. Este elemento se extiende desde la movilización de una logofilia cinematográfica latente, que sirve de contrapunto y enmarca, pasando por la creciente scopofilia del aparato cinematográfico en los casos ya explicados, hasta la frenética logofagia mediante la cual se movilizan imágenes visuales y temas en un intento de consumir - e incorporar - lo literario dentro de su propio marco totalizante. Que la literatura (la poesía en esta película) tenga que ser el primer significante del deseo, a pesar de que a la vez sea su expresión más cosificada, comprada y vendida como el sexo, promocionada por Oliverio entre el tráfico callejero, colgada para secar junto con la ropa, es testimonio de su lugar en el límite del régimen visual del cine. Como tal, la literatura se introduce a sí misma en el mismo espacio parergonal, ni del todo dentro, ni del todo fuera de la obra, consumida dentro de la constitución de un significante total en el cine, aunque marcando y regulando el límite del exceso cinematográfico, su especificidad e identidad.

Quizás la afirmación más “sincera” del deseo cinematográfico hacia la ficción, de la literatura como significante de ese deseo, si es que es posible la sinceridad dentro de la sala de espejos surgida de los encuadres que proliferan en estas películas, se encuentre en las palabras de Ana. Como ya le ocurriera a Estela, Ana está situada de modo ambiguo en un límite inestable entre el deseo por el significado (el cumplimiento de la representación) y el más absoluto vacío del significado, la futilidad de la ficción. Es un límite en el que el cuerpo se disuelve en la representación, lo estético se convierte en objeto de consumo, y las palabras se disuelven y surgen de las imágenes:

Nunca veas a una puta con luz de día.

Es como mirar una película con luz encendida.

Como el cabaret a las diez de la mañana con los rayos del sol atravesando el polvo

Que se levanta cuando barren.

Como descubrir que ese poema que te hizo llorar a la noche, al día siguiente apenas te interesa.

Es como sería este puto mundo si hubiera que soportar las cosas tal como son.

Como descubrir al actor que viste haciendo Hamlet en la cola del pan.

Como el vacío cuando te pagan y no sentís ni siquiera un poquito.

Como la tristeza cuando te pagan y sentiste por lo menos un poquito.

Como abrir un cajón y descubrir una foto de cuando la puta tenía nueve años.

Como dejarte venir conmigo sabiendo que cuando se acabe la magia vas a estar con una mujer como yo en Montevideo. (1:14)

Traducido por Irene Ruiz-Mora 
Alonso, Mauricio. “Esa insoportable levedad: El lado oscuro del corazón 2, de Eliseo Subiela”. Otrocampo 2001 (19-Sept.-2001). <http://www.otrocampo.com/criticas/ ladooscuro2.html>

Cohen, Keith. Film and Fiction: The Dynamics of Exchange. New Haven/Londres: Yale University Press, 1979.

Derrida, Jacques. The Truth in Painting. G. Bennington y I. McLeod, trad. Chicago: University of Chicago Press, 1987.

"Entrevista a Eliseo Subiela: el primer adelantado argentino”. Internet Surf (November 1999) 30-Sep-2001 <http://www.isurf.com.ar/99-11-noviembre/not_cin3.htm>

Forns-Broggi, Roberto. "Poesía y música en una ci(n)ta de amor: el uso de la reescritura poética y del bolero en El lado oscuro del corazón de Eliseo Subiela”. Romance Languages Annual [West Lafayette, IN] 8 (1997): 466-71.

Fuery, Patrick. New Developments in Film Theory. Basingstoke/Londres: Macmillan, 2000.

Girondo, Oliverio. Espantapájaros (al alcance de todos) [1932]. Buenos Aires: Losada, 1996.

Grant, Catherine. “Giving Up Ghosts: Eliseo Subiela’s Hombre mirando al sudeste and No te mueras sin decirme adónde vas”. Changing Reels: Latin American Cinema Against the Odds. Rob Rix y Roberto Rodríguez-Saona, eds. Leeds: Trinity y All Saints University College, 1997. 89-120.

Jameson, Fredric. The Geopolitical Fsthetic: Cinema and Space in the World System. Londres: British Film Institute, 1992.

Kantaris, Geoffrey. “The Last Snapshots of Modernity: Argentine Cinema after the 'Process'”. Bulletin of Hispanic Studies 73/2 (Glasgow, April 1996): 219-44. <http:/ /www.cus.cam.ac.uk/ egk10/notes/PD-ArgCinema, htm>

"Holograms and Simulacra: Bioy Casares, Subiela, Piglia”. (22-Mar- 2001 ). Centre of Latin American Studies, University of Cambridge <http:// www.latinamerican.cam.ac.uk/simulacra/>

Manetti, Ricardo. “Cine de autor”. Cine argentino en democracia 1983/1993. Claudio España, ed. Buenos Aires: Fondo Nacional de las Artes, 1994. 104-23.

Metz, Christian. Film Language: A Semiotics of the Cinema. Michael Taylor, trad. Nueva York: Oxford University Press, 1974.

Noriega, Gustavo. “El lado oscuro del corazón 2”. El amante cine 113 (Buenos Aires, 7Aug-2001). <http://elamante.com/nota/1/1984.shtml>

Page, Joanna. "Postmodernism, History and Social Critique in Post-Dictatorship Argentine Cinema: A Reading of Eliseo Subiela’s El lado oscuro del corazón”. The Modern Language Review 96/2 (Londres, April 2001): 385-96. <http://www.ingenta.com>

Pinkney, Tony. "Modernism and Cultural Theory". The Politics of Modernism: Against the New Conformists. Raymond Williams y Tony Pinkney, eds. Londres: Verso, 1989. 1-29.

Subiela, Eliseo, dir. El lado oscuro del corazón. Argentina: C. Q. 3 Films, 1992. Últimas imágenes del naufragio. Argentina: Cinequanon - TVE, 1989. 
Villegas, Juan. “El lado oscuro del corazón 2”. El amante cine 112 (Buenos Aires, 6-Jul2001). <http://elamante.com/nota/1/1035.shtml> 